\title{
HOW CHEST PRESS-BASED EXERCISES CAN ALLEVIATE THE BURDEN OF CARDIOVASCULAR DISEASES
}

review paper

() Wroclaw University of Health and Sport Sciences

DOI: https://doi.org/10.5114/hm.2021.106911

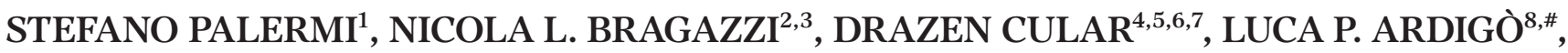 JOHNNY PADULO ${ }^{9, \#}$}

${ }^{1}$ Department of Public Health, University of Naples Federico II, Naples, Italy

${ }^{2}$ Laboratory for Industrial and Applied Mathematics, Department of Mathematics and Statistics, York University,

Toronto, Canada

${ }^{3}$ Postgraduate School of Public Health, Department of Health Sciences, University of Genoa, Genoa, Italy

${ }^{4}$ Laboratory for Applied Physiology, Sport Systems, Talents Development and Influence of Physical Activities on Health,

Faculty of Kinesiology, University of Split, Split, Croatia

${ }^{5}$ Croatian Institute for Kinesiology and Sport, Split, Croatia

${ }^{6}$ Einstein Craft for Research, Development, Education, Trade and Services, Split, Croatia

${ }^{7}$ Faculty of Kinesiology, University of Split, Split, Croatia

${ }^{8}$ School of Exercise and Sport Science, Department of Neurosciences, Biomedicine and Movement Sciences, University of Verona, Verona, Italy

${ }^{9}$ Department of Biomedical Sciences for Health, University of Milan, Milan, Italy

${ }^{\#}$ These authors share last authorship

\begin{abstract}
Unlike in the previous decades, strength training is gaining more scientific attention owing to its numerous benefits on human health. It has major benefits on metabolic processes, cardiovascular system, musculoskeletal system, age-related processes, and mental health. In comparison with aerobic low-intensity exercises, chest press-based strength training cardiovascular adaptations have been ignored for many years. Yet, if properly prescribed and conducted, strength training has shown to be safe and effective in people with cardiovascular disease. This narrative review aims at summarizing the available evidence about the role of chest press-based strength training on the cardiovascular system.
\end{abstract}

Key words: isokinetic machine, cardiovascular pathology, strength training

\section{Introduction}

Physical activity is universally recognized as a useful tool for prevention, treatment, and rehabilitation [1] of several diseases [2, 3], such as metabolic syndrome, cancer, pulmonary and cardiovascular illnesses [4]. Its efficacy has already been proved in numerous studies $[5,6]$, and the use of physical activity as an effective 'drug' is an emerging topic in scientific literature. Physical activity is organized in exercise programs oriented to strength development, low-intensity fitness, or a combination of these two. The design of a program must follow specific rules with regard to the exercise to be undertaken, as well as its intensity, duration, and frequency, in order to obtain benefits [7]. Strength exercises (or high-intensity exercise or resistance training) is a system of physical conditioning in which muscles are exercised by being worked against an opposite force to increase strength: it involves weight training or use of high-resistance machines and it is limited to few repetitions before exhaustion, since aerobic fitness is not its primary objective [8]. Low-intensity training involves exercise performed for extended periods with large muscle activity and numerous consecutive repetitions.

Correspondence address: Luca P. Ardigò, School of Exercise and Sport Science, Department of Neurosciences, Biomedicine and Movement Sciences, University of Verona, via Felice Casorati, 43, 37131 Verona, Italy, e-mail: luca.ardigo@univr.it

Received: January 3, 2021

Accepted for publication: May 4, 2021

Citation: Palermi S, Bragazzi NL, Cular D, Ardigò LP, Padulo J. How chest press-based exercises can alleviate the burden of cardiovascular diseases. Hum Mov. 2022;23(4):88-98; doi: https://doi.org/10.5114/hm.2021.106911. 
Examples of strength training include weight-lifting, resistance band exercises, use of body weight as resistance means (i.e., push-ups and pull-ups [9]), and use of gym weight machines such as leg press, curl bench, or chest press. Health benefits of strength training have been widely described in literature. A properly designed and supervised resistance training program with appropriate instructions for exercise technique is safe not only for healthy adults but also for people with major diseases [10], including cardiovascular pathologies. In this review, we aim at summarizing the available evidence on the role of chest press-based strength training in individuals with cardiovascular diseases.

\section{Strength training and health benefits}

While the benefits of aerobic low-intensity training have been largely investigated, strength training has not reached the same level of interest by both scientific community [7] and public opinion (Table 1). However, adults can gain other health benefits from this kind of training besides increased muscle mass and strength $[11,12]$. Studies have shown that strength exercises can improve bone mineral density [13, 14], lipoprotein profiles [15], glycaemic control [16], insulin resistance [17], and body composition [18]. They improve symptoms of frailty $[19,20]$ and quality of life in elderly patients [21], positively impact on metabolic syndrome risk factors [15] and resting metabolism [22], as well as reduce visceral adipose tissue [23]. Studies have further indicated that strength training can decrease the risk of all-cause mortality [24, 25] and counteract aging-related oxidative processes [26]. Moreover, it improves psychosocial health outcomes such as perceived stress [27], depression [28], anxiety [29], and fatigue [30]. Also, strength training has a certain effect in improving quality of life in people with disabilities [31]. It definitely plays a major role in human health, both mental and physical. Most workout programs included in this study consider chest press as one of the exercise machines, highlighting its importance and applicability in strength training.

\section{Chest press exercise}

Chest press is a classic upper-body strengthening exercise and it is often used as a measuring stick for evaluating upper body strength. One of the most common ways to effectively exercise at a bench press is when the barbell is first lowered to the chest and then moved to an extended position again [32]. It generally involves pectoralis major, pectoralis minor, anterior deltoids, and coracobrachialis to horizontally adduct the shoulder, whereas triceps and anconeus are used to extend the elbow. Exercise at bench press involves biceps and overall consists in an isotonic effort [33], against a predetermined resistance and over some range of movement [34]. This exercise should be adapted to the subject's needs and characteristics in terms of fitness, muscle strength, and joint mobility. There are variations in the elbow position that an individual can use when performing this exercise. It is commonly used in rehabilitation to strengthen neuromuscular and articular mobility [35]. External load is a crucial variable, which strictly influences the required muscular effort. It is linked to the maximum force (onerepetition maximum [1RM]) that a person is able to develop [36, 37], and this load is often higher than the body weight [38]. 1RM was inversely and independently associated with deaths of all causes and cancer in 8762 subjects [39] and with the risk of hypertension in prehypertensive man [40]. So, this is a very important value that must be considered regarding chest press exercise to plan safe and effective strength training. Apart from 1RM, other training load monitoring methods that showed a good efficacy in literature include session rating of perceived exertion [41].

Even if chest press exercise has been studied in literature with regard to its different aspects (i.e. its relationship with performance in athletes [42]), little is known about its role in cardiovascular diseases. Chest press elicits a large cardiovascular response [43] since exercises with upper limbs tend to carry greater cardiovascular overload than those performed with lower limbs [44]: probably, this is due to the smaller size of the vascular network present in the upper than lower limbs, which offers greater resistance to blood flow, resulting in higher myocardial demand and thereby considerably increased cardiovascular overload [45]. This is important as chest press has been associated with complications ranging in acuity from pectoral muscle strains to aortic and coronary artery dissection [46].

\section{Strength training and the cardiovascular system}

In comparison with low-intensity training, resistance training-induced favourable adaptations of the cardiovascular system have been ignored for many years, thus their mechanisms are still debated. Indeed, the underlying processes, hemodynamic adjustments, and autonomic contributions are not as well documented for strength workout as for low-intensity ex- 


\section{HUMAN MOVEMENT}

S. Palermi et al., Chest press and cardiovascular disease

Table 1. Health benefits of strength training

\begin{tabular}{|c|c|c|c|c|}
\hline Health benefit & $\begin{array}{c}\text { Characteristics } \\
\text { of strength training }\end{array}$ & Exercises & Study population & Reference \\
\hline $\begin{array}{l}\text { Increase of muscle } \\
\text { mass and strength }\end{array}$ & $\begin{array}{l}8 \text { weeks, } \\
3 \text { sessions per week, } \\
8-12 \text { repetitions } \\
\text { per exercise }\end{array}$ & $\begin{array}{l}\text { Flat/incline press, pull-down/row, } \\
\text { leg press/lungee/squat, standing calf } \\
\text { raises, shoulder press/lateral raises, } \\
\text { dumbbell curls/bench curls, triceps } \\
\text { push-down/extension, leg curl/back } \\
\text { extension }\end{array}$ & $\begin{array}{l}12 \text { males, } 7 \text { females } \\
\text { (age: } 34.64 \pm 6.91 \text { years) }\end{array}$ & {$[11,12]$} \\
\hline $\begin{array}{l}\text { Improvement } \\
\text { of bone mineral } \\
\text { density }\end{array}$ & $\begin{array}{l}16 \text { weeks, } \\
3 \text { sessions per week, } \\
8-15 \text { repetitions } \\
\text { per exercise }\end{array}$ & $\begin{array}{l}\text { Leg press, chest press, seated rows, } \\
\text { abdominal crunch, back extension, } \\
\text { seated leg curl, hip abduction }\end{array}$ & $\begin{array}{c}37 \text { females } \\
\text { (age: } 71.9 \pm 3.1 \text { years) }\end{array}$ & [13] \\
\hline $\begin{array}{l}\text { Improvement } \\
\text { of lipoprotein profile }\end{array}$ & $\begin{array}{l}8 \text { weeks, } \\
3 \text { sessions per week, } \\
10-15 \text { repetitions } \\
\text { per exercise }\end{array}$ & $\begin{array}{l}\text { Chest press, horizontal leg press, } \\
\text { seated row, knee extension, } \\
\text { preacher curl (free weights), leg curl, } \\
\text { triceps push-down, seated calf raise }\end{array}$ & $\begin{array}{c}65 \text { females } \\
\text { (age: } 68.9 \pm 6.1 \text { years) }\end{array}$ & [15] \\
\hline $\begin{array}{l}\text { Improvement } \\
\text { of glycaemic profile }\end{array}$ & $\begin{array}{l}16 \text { weeks, } \\
2 \text { sessions per week, } \\
8-15 \text { repetitions } \\
\text { per exercise }\end{array}$ & Squat, scission squat, crunches & $\begin{array}{c}5 \text { females, } 5 \text { males } \\
\text { (age: } 68.2 \pm 9.7 \text { years) }\end{array}$ & [16] \\
\hline $\begin{array}{l}\text { Improvement } \\
\text { of body composition }\end{array}$ & $\begin{array}{l}12 \text { weeks, } \\
2-3 \text { sessions per week, } \\
10-15 \text { repetitions } \\
\text { per exercise }\end{array}$ & $\begin{array}{l}\text { Chest press, horizontal leg press, } \\
\text { seated row, knee extension, } \\
\text { preacher curl, leg curl, triceps } \\
\text { push-down, seated calf raise }\end{array}$ & $\begin{array}{l}24 \text { females } \\
\text { (age: } 56.2 \pm 9.1 \text { years) }\end{array}$ & [18] \\
\hline $\begin{array}{l}\text { Decrease of frailty } \\
\text { symptoms }\end{array}$ & $\begin{array}{l}24 \text { weeks, } \\
2 \text { sessions per week }\end{array}$ & $\begin{array}{l}\text { Leg presses, knee extensions, } \\
\text { leg abduction, seated rowing }\end{array}$ & $\begin{array}{l}37 \text { females, } 4 \text { males } \\
\text { (age: } 81.5 \text { years) }\end{array}$ & [19] \\
\hline $\begin{array}{l}\text { Decrease of all-cause } \\
\text { mortality }\end{array}$ & $\begin{array}{l}48 \text { weeks, } \\
2 \text { sessions per week }\end{array}$ & $\begin{array}{l}\text { High-intensity progressive } \\
\text { resistance training }\end{array}$ & 124 subjects & [25] \\
\hline $\begin{array}{l}\text { Decrease of aging- } \\
\text { related oxidative } \\
\text { processes }\end{array}$ & $\begin{array}{l}14 \text { weeks, } \\
3 \text { sessions per week, } \\
10-12 \text { repetitions } \\
\text { per exercise }\end{array}$ & $\begin{array}{l}\text { Seated chest press, latissimus } \\
\text { pull-down, leg press, military press, } \\
\text { calf raise, arm extension, back } \\
\text { extension, abdominal crunch, upright } \\
\text { row, knee extension, knee flexion }\end{array}$ & $\begin{array}{l}14 \text { females, } 14 \text { males } \\
\text { (age: } 68.5 \pm 5.1 \text { years) }\end{array}$ & {$[26]$} \\
\hline $\begin{array}{l}\text { Improvement } \\
\text { of mental illnesses }\end{array}$ & $\begin{array}{l}12 \text { weeks, } \\
60 \text { min weekly }+ \\
2 \text { sessions at home } \\
30 \text { min each }\end{array}$ & Progressive resistance training & $\begin{array}{l}19 \text { females, } 13 \text { males } \\
\text { (age: } 56.3 \pm 8.1 \text { years) }\end{array}$ & {$[27]$} \\
\hline $\begin{array}{l}\text { Improvement } \\
\text { of quality of life } \\
\text { in people with } \\
\text { disabilities }\end{array}$ & $\begin{array}{l}24 \text { weeks, } \\
3 \text { sessions per week, } \\
20 \text { repetitions } \\
\text { per exercise }\end{array}$ & $\begin{array}{l}\text { Leg extension, leg press, leg curl, } \\
\text { shoulder press, arm curls, lateral } \\
\text { pull-down, bench press, triceps } \\
\text { extension }\end{array}$ & $\begin{array}{c}30 \text { females } \\
\text { (age: } 70.6 \pm 4.5 \text { years) }\end{array}$ & [31] \\
\hline
\end{tabular}


ercise [47]. However, as scientifically validated [48], prescribed and supervised strength training has a favourable effect in people with cardiovascular disease, improving their muscle strength and endurance, functional skills, and independence: so, it has a major role in reducing disability. Several mechanisms have been proposed to explain why muscle strength may improve prognosis of cardiovascular disease [49], and these include reducing abdominal fat, improving values of metabolic syndrome components (blood pressure [BP], waist circumference, triglycerides, glycaemia, and cholesterol), decreasing the risk of developing hypertension, cutting down insulin resistance, and decreasing chronic inflammation biomarkers. The effects of resistance training on the cardiovascular system have been studied in individuals with and without cardiovascular diseases and have been summarized in several reviews [50]. During isometric exercise, typical of strength training, increases in heart rate (HR) and BP are nearly proportional to the force exerted (Table 2 [51]). Combination of vasoconstriction and increased cardiac output results in a disproportionate rise in HR and BP. The impact of the Valsalva manoeuvre (a forced expiration against a closed glottis) and high levels of muscle tension to lift can result in dramatic changes to physiological responses to strength training. Depending on its duration and intensity, an increase in intrathoracic pressure leading to decreased venous return and potentially reduced cardiac output may occur [52, 53]. During heavy resistance exercise, especially if accompanied by the Valsalva manoeuvre, symptoms of light-headedness or dizziness may occur if cardiac output is reduced. Syncope is therefore one of the worst adverse effects in subjects with cardiovascular disease $[54,55]$. However, a smaller pressure load on the cardiovascular system will occur during this type of exercise if relative resistance is not too great, contraction period is relatively short (1-3 seconds), and there is at least a 1-2-second rest period between contractions [55]: these are important precautions to take in consideration. However, such potential HR and BP responses are very unlikely to occur

Table 2. Cardiovascular adaptations to strength training

\begin{tabular}{|c|c|c|c|c|}
\hline $\begin{array}{l}\text { Cardiovascular } \\
\text { adaptations }\end{array}$ & $\begin{array}{l}\text { Characteristics } \\
\text { of strength training }\end{array}$ & Exercises & Study population & Reference \\
\hline $\begin{array}{l}\text { Increase of HR } \\
\text { and BP (short term) }\end{array}$ & $\begin{array}{l}2 \text { min of contraction } \\
\text { per exercise }\end{array}$ & $\begin{array}{l}\text { Adductions of digits II and III, } \\
\text { handgrip, knee extension }\end{array}$ & $\begin{array}{l}11 \text { males } \\
\text { (age: } 23 \text { years) }\end{array}$ & {$[51]$} \\
\hline $\begin{array}{l}\text { Decrease of venous } \\
\text { return to heart }\end{array}$ & $\begin{array}{l}50-75-100 \% \text { of } 4 \mathrm{RM} \\
\text { per exercise }\end{array}$ & $\begin{array}{l}\text { Deadlift, slide row, leg press, } \\
\text { bench press, box lift, vertical jump, } \\
\text { drop jump, Valsalva manoeuvre }\end{array}$ & 11 males & [52] \\
\hline $\begin{array}{l}\text { Increase of LV wall } \\
\text { thickness and mass }\end{array}$ & $\begin{array}{l}\text { Weight-lifters engaged } \\
\text { in serious power-lifting } \\
\text { for at least } 2 \text { years and } \\
\text { trained at least } 3 \text { times } \\
\text { per week for several hours }\end{array}$ & $\begin{array}{l}\text { All weight lifters could bench-press } \\
\text { at least } 250 \text { pounds }(113 \mathrm{~kg})\end{array}$ & $\begin{array}{l}65 \text { subjects } \\
\text { (age: } 19-38 \text { years) }\end{array}$ & [64] \\
\hline $\begin{array}{l}\text { No deterioration } \\
\text { in } \mathrm{LV} \text { function }\end{array}$ & $\begin{array}{l}1 \text { set, } 10 \text { repetitions } \\
\text { per exercise }\end{array}$ & $\begin{array}{l}\text { Leg press, shoulder press, } \\
\text { biceps curl }\end{array}$ & $\begin{array}{l}5 \text { females, } 7 \text { males } \\
\text { (age: } 62 \pm 9 \text { years) }\end{array}$ & {$[67]$} \\
\hline $\begin{array}{l}\text { Decrease of HR } \\
\text { and BP (long term) }\end{array}$ & $\begin{array}{l}24 \text { weeks, } \\
3 \text { sessions per week, } \\
15 \text { repetitions } \\
\text { per exercise }\end{array}$ & $\begin{array}{l}\text { Unilateral leg press, chest press, } \\
\text { unilateral leg curl, lateral pull-down, } \\
\text { unilateral leg extension, overhead } \\
\text { shoulder press, upper back rowing, } \\
\text { triceps push-down, abdominal } \\
\text { crunch }\end{array}$ & 23 females & [68] \\
\hline $\begin{array}{l}\text { Improvement } \\
\text { of oxygen balance }\end{array}$ & $\begin{array}{l}\text { Maximal number } \\
\text { of repetitions }\end{array}$ & $\begin{array}{l}\text { Overhead press, biceps curl, } \\
\text { quadriceps extension, supine press }\end{array}$ & $\begin{array}{c}12 \text { males } \\
\text { (age: } 55 \pm 9 \text { years) }\end{array}$ & [69] \\
\hline $\begin{array}{l}\text { Reduction of } \\
\text { vasoconstrictor } \\
\text { substances }\end{array}$ & $\begin{array}{l}8 \text { weeks, } \\
3 \text { sessions per week, } \\
10 \text { repetitions } \\
\text { per exercise }\end{array}$ & $\begin{array}{l}\text { Squats, leg extensions, leg curls, } \\
\text { bench presses, lateral pull-downs, } \\
\text { abdominal crunch }\end{array}$ & $\begin{array}{c}15 \text { males } \\
\text { (age: } 21 \pm 1.5 \text { years) }\end{array}$ & {$[71]$} \\
\hline
\end{tabular}

HR - heart rate, $\mathrm{BP}$ - blood pressure, $\mathrm{LV}$ - left ventricle, $\mathrm{RM}$ - repetition maximum 
Table 3. Cardiovascular diseases that benefit from strength training

\begin{tabular}{|c|c|c|c|c|}
\hline $\begin{array}{l}\text { Cardiovascular } \\
\text { disease }\end{array}$ & $\begin{array}{l}\text { Characteristics } \\
\text { of strength training }\end{array}$ & Exercises & Study population & Reference \\
\hline $\begin{array}{l}\text { High blood } \\
\text { pressure }\end{array}$ & $\begin{array}{l}24 \text { weeks, } \\
3 \text { sessions per week, } \\
10-15 \text { repetitions } \\
\text { per exercise }\end{array}$ & $\begin{array}{l}\text { Latissimus dorsi pull-down, leg extension, } \\
\text { leg curl, bench press, leg press, shoulder } \\
\text { press, seated mid-rowing + low-intensity } \\
\text { exercise }\end{array}$ & $\begin{array}{c}104 \text { subjects } \\
\text { (age: } 63.6 \pm 5.7 \text { years) }\end{array}$ & [74] \\
\hline $\begin{array}{l}\text { Coronary artery } \\
\text { disease }\end{array}$ & Weight carrying test & $\begin{array}{l}5 \text { min of treadmill ambulation with graded } \\
\text { weight loads of } 10-30 \text { pounds }(5-15 \mathrm{~kg})\end{array}$ & 27 males & [81] \\
\hline $\begin{array}{l}\text { Congestive heart } \\
\text { failure }\end{array}$ & $\begin{array}{l}11 \text { weeks, } 30-60 \mathrm{~s} \\
\text { per exercise }\end{array}$ & $\begin{array}{l}\text { Chest push-pull, knee extension/flexion, } \\
\text { shoulder push-pull }\end{array}$ & $\begin{array}{c}9 \text { males } \\
\text { (age: } 63 \pm 11 \text { years) }\end{array}$ & [84] \\
\hline Atrial fibrillation & $\begin{array}{l}6 \text { weeks, } 3 \text { sessions } \\
\text { per week }\end{array}$ & $\begin{array}{l}\text { Strengthening exercise for the back, thighs, } \\
\text { and stomach + low-intensity exercise }\end{array}$ & $\begin{array}{l}2 \text { females, } 28 \text { males } \\
\text { (age: } 64 \pm 7 \text { years) }\end{array}$ & [89] \\
\hline
\end{tabular}

with appropriate instruction and supervision of strength training participants, owing to relatively moderate intensities of effort [56].

The prescription of strength training therefore involves the control of several variables, such as number of sets and repetitions, order of exercises, type of exercises, interval time, speed, intensity, and rest interval [57]. Such variables can trigger different physiological responses, having a direct impact on cardiovascular safety during training [58], and therefore these are absolutely crucial to control in training programming in cardiac patients. A safe strength training should take in consideration low intensity and high number of repetitions [11, 59], adequate rest interval [60], and little time under tension [61]. It should be individualized for the patients we are prescribing for. Also, the bench press exercise performed with low volume and high intensity promotes a more pronounced cardiovascular response than the same exercise performed with high volume and low intensity [59, 62]. Moreover, breathing is crucial to avoid the Valsalva manoeuvre and a subsequent increase in HR and BP: inhaling during the lowering (eccentric) phase of the bench press and exhaling during the lifting (concentric) phase are important aims to reach [63].

Although equivocal results exist, intensive resistance training has been found to characteristically increase left ventricular (LV) wall thickness and mass, with little or no change in LV diameter [50, 64, 65]. Both systolic and diastolic LV function (assessed with the determinants of LV filling velocities and relaxation by non-invasive imaging methods) was normal after strength training and consistent with physiological hypertrophy [65-67]. Even if resistance training does not impose a large low-intensity burden, some studies have demonstrated a modest increase in peak oxygen uptake and long-term decreases in submaximal HR and systolic BP [68]. It appears that mild- to moderate-intensity resistance exercise evokes a lower rate-pressure product, an indirect index of myocardial oxygen demand [69]. Therefore, it seems to promote a better balance between oxygen support and demand [70]. Furthermore, strength training reduces plasma concentration of endothelin-1, a potent vasoconstrictor and vascular smooth muscle proliferative agent, in young men [71, 72]. Moreover, some studies in older adults suggest that low- to moderate-intensity training may attenuate oxidative stress markers [26], promoters of the atherosclerosis process.

\section{Strength training and cardiovascular diseases}

Although some absolute contraindications exist (unstable angina, uncontrolled arrhythmias or hypertension, severe and symptomatic aortic and pulmonary stenosis) [48], controlled strength physical activity can be performed safely and positively in numerous cardiovascular conditions, often combined with lowintensity exercise (Table 3). Much evidence highlights the benefits of strength training in decreasing BP $[73,74]$, and the improvement of BP profile results in lower rates of major cardiovascular events and death of any cause [75]. With an adequate weight, short contraction time, and enough between-contraction rest time, 20-30 repetitions can be performed safely [48] in a hypertensive patient. Many papers [70, 74-76] emphasize this anti-hypertensive role of resistance training. To prevent BP increase, breathing correctly and avoiding the Valsalva manoeuvre are crucial when performing this type of exercise. Individuals with controlled hypertension and no cardiovascular or renal 
complications may participate in an exercise or competitive program, but should be evaluated, treated, and monitored closely [77].

Strength training combined with aerobic low-intensity training is well tolerated in patients with coronary syndrome and the combination is associated with improvements of their quality of life [78], strength, and endurance [79]. Strength exercise can be initiated approximately 3 weeks after stent implantation or 5 weeks after bypass surgery [80]. There are reports [81] that light weightlifting activity is safe in heart attack patients only after 3 weeks from the event. A special consideration for coronary artery bypass graft patients is to avoid heavy loads being placed upon the chest to allow for proper scar healing [56]. Moreover, a recent meta-analysis found that resistance training was associated with reductions in cardiac mortality, recurrence of myocardial infarction, repeated percutaneous coronary intervention, coronary artery bypass grafting, and restenosis [82]. Moreover, decreased mortality and hospital readmission for coronary artery disease were observed in patients undergoing specific training sessions [83].

Selected patients with congestive heart failure and coronary heart disease respond to strength training safely and effectively [72, 84]. There is strong scientific evidence [85] that the application of specific dynamic resistance training is safe and induces significant muscular adaptations in screened heart failure individuals. Indeed, it seems to efficiently treat specific myopathy and muscle weakness occurring in the majority of these patients. Also, increasing peak oxygen uptake in their exercise capacity [86], this training protocol could provide several health-related and socioeconomic benefits in this common syndrome.

Patients with atrial fibrillation often report such symptoms as fatigue, decreased exercise tolerance, dyspnoea, and palpitations, leading to a reduced quality of life [87]. Therefore, achieving significant improvements in exercise capacity through a short-term exercise training program [88] could be primary for these subjects. Further studies support these findings [89, 90]. Moreover, a report [91] showed that moderate physical exercises performed for 45 minutes twice a week decreased HR significantly after 4 months and helped to control this arrhythmia. Therefore, although atrial fibrillation could be triggered by exercise itself [92], it is recommended that these patients undergo controlled and safe physical activity [93].

\section{Strength training and guidelines}

According to the World Health Organization advice, adults should undertake at least 150 minutes of low- to moderate-intensity physical activity weekly, with at least 2 days of muscle-strengthening activities [94]. Strength training is an important component of training programs for health and physical well-being as for both the 2000 American Heart Association recommendations [56] and the 2020 American College of Sports Medicine guidelines [10].

Facts to consider before exercise include: type of disease, co-morbidities and medical history, ejection fraction, cardiovascular risk factors, exercise capacity, physical limitations, symptoms, medications, physical activity level. The general recommendations for a correct development of a strength exercise workout include 1-3 sets per exercise per muscle group, 8-15 repetitions, 2-3 days per week, with exercises to mimic tasks of daily living [95]. Traditional strength training for cardiovascular subjects includes, for each exercise, 3 sets of 10 repetitions 2-3 times a week [10]. Load choice is important, but a light weight can be lifted early in a rehabilitation protocol [81]. In low-risk patients with cardiovascular disease, loads of 8-15 $1 \mathrm{RM}$ have been deemed safe $[48,96]$. Initial loads should be equal to 50-60\% 1RM for lower extremities and $30-40 \% 1 \mathrm{RM}$ for upper extremities, and intensity should be increased when subjects complete 2-3 sets of 12-15 repetitions at a given load [80]. Subjects should perform 1-2 sets of 8-10 exercises for all major muscle groups 2-3 days per week, with 48 hours between sessions and between-set recovery of 30-120 seconds [80]. The use of exercise machines is strongly suggested owing to their load adjustment feature, reducing the risk of accidents. Chest press application [36] has been shown to be a safe and well-structured form of physical exercise: it can be easily supervised and load can be controlled [11]. Regular monitoring of HR and BP during each session is advised to ensure that cardiovascular responses to exercise are normal. It is suggested that these patients undergo a complete medical evaluation by a sports physician before beginning the training protocols [77, 97]. Moreover, the physical exercise should be monitored by a prepared personal trainer [98]. Indeed, it is not recommended that these subjects exercise on their own because of the high risks to their health [99]. Safe and controlled physical activity is mandatory to reach the set goals and to avoid adverse effects. 


\section{Conclusions}

The available scientific evidence supports the usefulness of strength training, in particular chest pressbased exercise, in people with cardiovascular diseases. Studies show that, if properly prescribed and conducted, strength training is safe, does not lead to significant complications, and can have major benefits and advantages. It is, however, recommended that the patients undergo a preventive full medical screening and an effective monitoring during their training. $\mathrm{Fu}-$ ture large high-quality randomized controlled clinical trials are necessary to confirm these findings.

\section{Ethical approval}

The conducted research is not related to either human or animal use.

\section{Disclosure statement}

No author has any financial interest or received any financial benefit from this research.

\section{Conflict of interest}

The authors state no conflict of interest.

\section{References}

1. Martínez-Velilla N, Cadore EL, Casas-Herrero Á, IdoateSaralegui F, Izquierdo M. Physical activity and early rehabilitation in hospitalized elderly medical patients: systematic review of randomized clinical trials. J Nutr Health Aging. 2016;20(7):738-751; doi: 10.1007/s12603 -016-0683-4.

2. Pedersen BK, Saltin B. Evidence for prescribing exercise as therapy in chronic disease. Scand J Med Sci Sports. 2006;16(Suppl. 1):3-63; doi: 10.1111/j.16000838.2006.00520.x.

3. Adami PE, Negro A, Lala N, Martelletti P. The role of physical activity in the prevention and treatment of chronic diseases. Clin Ter. 2010;161(6):537-541.

4. Kruk J. Physical activity in the prevention of the most frequent chronic diseases: an analysis of the recent evidence. Asian Pac J Cancer Prev. 2007;8(3):325-338.

5. Fiuza-Luces C, Garatachea N, Berger NA, Lucia A. Exercise is the real polypill. Physiology. 2013;28(5):330358; doi: 10.1152/physiol.00019.2013.

6. Warburton DER, Nicol CW, Bredin SSD. Health benefits of physical activity: the evidence. CMAJ. 2006; 174(6):801-809; doi: 10.1503/cmaj.051351.

7. Knuttgen HG. Strength training and aerobic exercise: comparison and contrast. J Strength Cond Res. 2007; 21(3):973-978; doi: 10.1519/R-505011.1.

8. Chamari K, Padulo J. 'Aerobic' and 'anaerobic' terms used in exercise physiology: a critical terminology reflection. Sports Med Open. 2015;1(1):9; doi: 10.1186/ s40798-015-0012-1.
9. Dhahbi W, Chaabene H, Chaouachi A, Padulo J, Behm DG, Cochrane J, et al. Kinetic analysis of pushup exercises: a systematic review with practical recommendations. Sports Biomech. 2018;1-40; doi: 10.1080/ 14763141.2018.1512149.

10. American College of Sports Medicine. ACSM's guidelines for exercise testing and prescription. Philadelphia: Lippincott Williams \& Wilkins; 2020.

11. Souza D, Barbalho M, Gentil P. The impact of resistance training volume on muscle size and lean body mass: to infinity and beyond? Hum Mov. 2020;21(4): 18-29; doi: 10.5114/hm.2020.94199.

12. Thomas MH, Burns SP. Increasing lean mass and strength: a comparison of high frequency strength training to lower frequency strength training. Int J Exerc Sci. 2016;9(2):159-167.

13. Huovinen V, Ivaska KK, Kiviranta R, Bucci M, Lipponen $H$, Sandboge $S$, et al. Bone mineral density is increased after a 16 -week resistance training intervention in elderly women with decreased muscle strength. Eur J Endocrinol. 2016;175(6):571-582; doi: 10.1530/ EJE-16-0521.

14. Anek A, Kanungsukasem V, Bunyaratavej N. Effects of aerobic step combined with resistance training on biochemical bone markers, health-related physical fitness and balance in working women. J Med Assoc Thai. 2015;98(Suppl. 8):S42-S51.

15. Ribeiro AS, Tomeleri CM, Souza MF, Pina FLC, Schoenfeld BJ, Nascimento MA, et al. Effect of resistance training on C-reactive protein, blood glucose and lipid profile in older women with differing levels of RT experience. Age. 2015;37(6):109; doi: 10.1007/s11357-015-9849-y.

16. Takenami E, Iwamoto S, Shiraishi N, Kato A, Watanabe Y, Yamada Y, et al. Effects of low-intensity resistance training on muscular function and glycemic control in older adults with type 2 diabetes. J Diabetes Investig. 2019;10(2):331-338; doi: 10.1111/jdi.12926.

17. Pollock ML, Vincent KR. Resistance training for health. Pres Counc Phys Fit Sports Res Dig. 1996;2(8).

18. Cavalcante EF, Ribeiro AS, do Nascimento MA, Silva AM, Tomeleri CM, Nabuco HCG, et al. Effects of different resistance training frequencies on fat in overweight/ obese older women. Int J Sports Med. 2018;39(7):527534; doi: 10.1055/a-0599-6555.

19. Nagai K, Miyamato T, Okamae A, Tamaki A, Fujioka H, Wada Y, et al. Physical activity combined with resistance training reduces symptoms of frailty in older adults: a randomized controlled trial. Arch Gerontol Geriatr. 2018;76:41-47; doi: 10.1016/j.archger.2018. 02.005 .

20. Fiatarone MA, O’Neill EF, Ryan ND, Clements KM, Solares GR, Nelson ME, et al. Exercise training and nutritional supplementation for physical frailty in very elderly people. N Engl J Med. 1994;330(25):1769-1775; doi: 10.1056/NEJM199406233302501.

21. Ades PA, Ballor DL, Ashikaga T, Utton JL, Nair KS. Weight training improves walking endurance in healthy 
elderly persons. Ann Intern Med. 1996;124(6):568-572; doi: 10.7326/0003-4819-124-6-199603150-00005.

22. Pratley R, Nicklas B, Rubin M, Miller J, Smith A, Smith M, et al. Strength training increases resting metabolic rate and norepinephrine levels in healthy 50to 65-yr-old men. J Appl Physiol. 1994;76(1):133-137; doi: 10.1152/jappl.1994.76.1.133.

23. Treuth MS, Hunter GR, Kekes-Szabo T, Weinsier RL, Goran MI, Berland L. Reduction in intra-abdominal adipose tissue after strength training in older women. J Appl Physiol. 1995;78(4):1425-1431; doi: 10.1152/ jappl.1995.78.4.1425.

24. Kraschnewski JL, Sciamanna CN, Poger JM, Rovniak LS, Lehman EB, Cooper AB, et al. Is strength training associated with mortality benefits? A 15year cohort study of US older adults. Prev Med. 2016;87:121-127; doi: 10.1016/j.ypmed.2016.02.038.

25. Singh NA, Quine S, Clemson LM, Williams EJ, Williamson DA, Stavrinos TM, et al. Effects of high-intensity progressive resistance training and targeted multidisciplinary treatment of frailty on mortality and nursing home admissions after hip fracture: a randomized controlled trial. J Am Med Dir Assoc. 2012; 13(1):24-30; doi: 10.1016/j.jamda.2011.08.005.

26. Parise G, Brose AN, Tarnopolsky MA. Resistance exercise training decreases oxidative damage to DNA and increases cytochrome oxidase activity in older adults. Exp Gerontol. 2005;40(3):173-180; doi: 10.1016/j. exger.2004.09.002.

27. Putiri AL, Lovejoy JC, Gillham S, Sasagawa M, Bradley R, Sun G-C. Psychological effects of Yi Ren Medical Qigong and progressive resistance training in adults with type 2 diabetes mellitus: a randomized controlled pilot study. Altern Ther Health Med. 2012;18(1):30-34.

28. Sparrow D, Gottlieb DJ, Demolles D, Fielding RA. Increases in muscle strength and balance using a resistance training program administered via a telecommunications system in older adults. J Gerontol A Biol Sci Med Sci. 2011;66(11):1251-1257; doi: 10.1093/ gerona/glr138.

29. Ferreira RM, da Costa Alves WMG, de Lima TA, Alves TGG, Alves Filho PAM, Pimentel CP, et al. The effect of resistance training on the anxiety symptoms and quality of life in elderly people with Parkinson's disease: a randomized controlled trial. Arq Neuropsiquiatr. 2018;76(8):499-506; doi: 10.1590/0004-282X20180071.

30. Schmidt T, Weisser B, Jonat W, Baumann FT, Mundhenke C. Gentle strength training in rehabilitation of breast cancer patients compared to conventional therapy. Anticancer Res. 2012;32(8):3229-3233.

31. Brochu M, Savage P, Lee M, Dee J, Cress ME, Poehlman ET, et al. Effects of resistance training on physical function in older disabled women with coronary heart disease. J Appl Physiol. 2002;92(2):672-678; doi: 10.1152/japplphysiol.00804.2001.

32. Van den Tillaar R, Ettema G. A comparison of muscle activity in concentric and counter movement maximum bench press. J Hum Kinet. 2013;38:63-71; doi: 10.2478/ hukin-2013-0046.

33. McArdle WD, Katch FI, Katch VL. Exercise physiology: nutrition, energy, and human performance. Philadelphia: Lippincott Williams \& Wilkins; 2010.

34. Baechle TR, Earle RW. Essentials of strength training and conditioning. Champaign: Human Kinetics; 2008.

35. Fong SSM, Tam YT, Macfarlane DJ, Ng SSM, Bae Y-H, Chan EWY, et al. Core muscle activity during TRX suspension exercises with and without kinesiology taping in adults with chronic low back pain: implications for rehabilitation. Evid Based Complement Alternat Med. 2015;2015:910168; doi: 10.1155/2015/910168.

36. Padulo J, Laffaye G, Chaouachi A, Chamari K. Bench press exercise: the key points. J Sports Med Phys Fitness. 2015;55(6):604-608.

37. Padulo J, Mignogna P, Mignardi S, Tonni F, D’Ottavio S. Effect of different pushing speeds on bench press. Int J Sports Med. 2012;33(5):376-380; doi: 10.1055/ s-0031-1299702.

38. Reynolds JM, Gordon TJ, Robergs RA. Prediction of one repetition maximum strength from multiple repetition maximum testing and anthropometry. J Strength Cond Res. 2006;20(3):584-592; doi: 10.1519/R-15304.1.

39. Ruiz JR, Sui X, Lobelo F, Morrow JR, Jackson AW, Sjöström M, et al. Association between muscular strength and mortality in men: prospective cohort study. BMJ. 2008;337(7661):a439; doi: 10.1136/bmj.a439.

40. Maslow AL, Sui X, Colabianchi N, Hussey J, Blair SN. Muscular strength and incident hypertension in normotensive and prehypertensive men. Med Sci Sports Exerc. 2010;42(2):288-295; doi: 10.1249/MSS.0b013 e3181b2f0a4.

41. Haddad M, Stylianides G, Djaoui L, Dellal A, Chamari K. Session-RPE method for training load monitoring: validity, ecological usefulness, and influencing factors. Front Neurosci. 2017;11:612; doi: 10.3389/fnins.2017. 00612.

42. Molacek ZD, Conley DS, Evetovich TK, Hinnerichs KR. Effects of low- and high-volume stretching on bench press performance in collegiate football players. J Strength Cond Res. 2010;24(3):711-716; doi: 10.1519/ JSC.0b013e3181c7c242.

43. Pinto RR, Polito MD. Haemodynamic responses during resistance exercise with blood flow restriction in hypertensive subjects. Clin Physiol Funct Imaging. 2016; 36(5):407-413; doi: 10.1111/cpf.12245.

44. Moreira OC, Faraci LL, de Matos DG, Mazini Filho ML, da Silva SF, Aidar FJ, et al. Cardiovascular responses to unilateral, bilateral, and alternating limb resistance exercise performed using different body segments. J Strength Cond Res. 2017;31(3):644-652; doi: 10.1519/ JSC.0000000000001160.

45. MacDougall JD, Tuxen D, Sale DG, Moroz JR, Sutton JR. Arterial blood pressure response to heavy resistance exercise. J Appl Physiol. 1985;58(3):785-790; doi: 10.1152/jappl.1985.58.3.785. 
46. Smereck JA, Papafilippaki A, Sudarshan S. Acute chest pain after bench press exercise in a healthy young adult. Open Access Emerg Med. 2016;8:73-76; doi: 10.2147/ OAEM.S114310.

47. Romero SA, Minson CT, Halliwill JR. The cardiovascular system after exercise. J Appl Physiol. 2017;122(4): 925-932; doi: 10.1152/japplphysiol.00802.2016.

48. Williams MA, Haskell WL, Ades PA, Amsterdam EA, Bittner V, Franklin BA, et al. Resistance exercise in individuals with and without cardiovascular disease: 2007 update: a scientific statement from the American Heart Association Council on Clinical Cardiology and Council on Nutrition, Physical Activity, and Metabolism. Circulation. 2007;116(5):572-584; doi: 10.1161/ CIRCULATIONAHA.107.185214.

49. Artero EG, Lee D-C, Lavie CJ, España-Romero V, Sui X, Church TS, et al. Effects of muscular strength on cardiovascular risk factors and prognosis. J Cardiopulm Rehabil Prev. 2012;32(6):351-358; doi: 10.1097/HCR. 0b013e3182642688.

50. Spirito P, Pelliccia A, Proschan MA, Granata M, Spataro A, Bellone P, et al. Morphology of the 'athlete's heart' assessed by echocardiography in 947 elite athletes representing 27 sports. Am J Cardiol. 1994;74(8):802806; doi: 10.1016/0002-9149(94)90439-1.

51. Mitchell JH, Payne FC, Saltin B, Schibye B. The role of muscle mass in the cardiovascular response to static contractions. J Physiol. 1980;309:45-54; doi: 10.1113/ jphysiol.1980.sp013492.

52. Harman EA, Frykman PN, Clagett ER, Kraemer WJ. Intra-abdominal and intra-thoracic pressures during lifting and jumping. Med Sci Sports Exerc. 1988;20(2): 195-201; doi: 10.1249/00005768-198820020-00015.

53. Ricci F, Sutton R, Palermi S, Tana C, Renda G, Gallina $S$, et al. Prognostic significance of noncardiac syncope in the general population: a systematic review and meta-analysis. J Cardiovasc Electrophysiol. 2018;29(12): 1641-1647; doi: 10.1111/jce.13715.

54. Murrell C, Cotter JD, George K, Shave R, Wilson L, Thomas K, et al. Influence of age on syncope following prolonged exercise: differential responses but similar orthostatic intolerance. J Physiol. 2009;587(Pt 24):5959 -5969; doi: 10.1113/jphysiol.2009.179549.

55. McCartney N. Acute responses to resistance training and safety. Med Sci Sports Exerc. 1999;31(1):31-37; doi: 10.1097/00005768-199901000-00007.

56. Pollock ML, Franklin BA, Balady GJ, Chaitman BL, Fleg JL, Fletcher B, et al. Resistance exercise in individuals with and without cardiovascular disease: benefits, rationale, safety, and prescription: an advisory from the Committee on Exercise, Rehabilitation, and Prevention, Council on Clinical Cardiology, American Heart Association. Circulation. 2000;101(7):828-833; doi: 10.1161/01.cir.101.7.828.

57. Poton R, Polito MD. Hemodynamic response to resistance exercise with and without blood flow restriction in healthy subjects. Clin Physiol Funct Imaging. 2016; 36(3):231-236; doi: 10.1111/cpf.12218.

58. De Jesus RCA, Moreira OC, de Oliveira CEP, Doimo LA, Monteiro WD. Cardiovascular response in three different resistance exercises to the deltoid muscle [in Portuguese]. Biosci J. 2013;29(6):2077-2084.

59. Moreira OC, Oliveira CEP, Matos DG, Silva SF, Hickner RC, Aidar FJ. Cardiovascular response to strength training is more affected by intensity than volume in healthy subjects. Rev Andal Med Deporte. 2018;11(3): 1-5; doi: 10.1016/j.ramd.2017.01.002.

60. Lamotte M, Fleury F, Pirard M, Jamon A, van de Borne P. Acute cardiovascular response to resistance training during cardiac rehabilitation: effect of repetition speed and rest periods. Eur J Cardiovasc Prev Rehabil. 2010; 17(3):329-336; doi: 10.1097/HJR.0b013e328332efdd.

61. Burd NA, Andrews RJ, West DWD, Little JP, Cochran AJR, Hector AJ, et al. Muscle time under tension during resistance exercise stimulates differential muscle protein sub-fractional synthetic responses in men. J Physiol. 2012;590(2):351-362; doi: 10.1113/jphysiol. 2011.221200.

62. Dias MRC, de Matos DG, Mazini Filho ML, Moreira OC, Hickner RC, Cardozo D, et al. Comparison of repetition number between uni-joint and multi-joint exercises with 1-min and 2-min rest intervals. JEP online. 2014; 17(4):93-101.

63. Lepley AS, Hatzel BM. Effects of weightlifting and breathing technique on blood pressure and heart rate. J Strength Cond Res. 2010;24(8):2179-2183; doi: 10.1519/JSC.0b013e3181e2741d.

64. Pearson AC, Schiff M, Mrosek D, Labovitz AJ, Williams GA. Left ventricular diastolic function in weight lifters. Am J Cardiol. 1986;58(13):1254-1259; doi: 10.1016/0002-9149(86)90392-9.

65. D’Andrea A, Bossone E, Radmilovic J, Caso P, Calabrò R, Russo MG, et al. The role of new echocardiographic techniques in athlete's heart. F1000Res. 2015;4:289; doi: 10.12688/f1000research.6745.1.

66. D’Andrea A, Mele D, Palermi S, Rizzo M, Campana M, Di Giannuario G, et al. The "gray areas" of cardiovascular adaptations to physical exercise: how to orient yourself in the echocardiographic assessment of the athlete's heart [in Italian]. G Ital Cardiol. 2020;21(6): 457-468; doi: 10.1714/3359.33330.

67. Karlsdottir AE, Foster C, Porcari JP, Palmer-McLean K, White-Kube R, Backes RC. Hemodynamic responses during aerobic and resistance exercise. J Cardiopulm Rehabil.2002;22(3):170-177; doi: 10.1097/00008483200205000-00008.

68. Martel GF, Hurlbut DE, Lott ME, Lemmer JT, Ivey FM, Roth SM, et al. Strength training normalizes resting blood pressure in 65- to 73-year-old men and women with high normal blood pressure. J Am Geriatr Soc. 1999;47(10):1215-1221; doi: 10.1111/j.1532-5415.1999. tb05202.x. 
69. Featherstone JF, Holly RG, Amsterdam EA. Physiologic responses to weight lifting in coronary artery disease. Am J Cardiol. 1993;71(4):287-292; doi: 10.1016/00029149(93)90792-b.

70. Pescatello LS, Franklin BA, Fagard R, Farquhar WB, Kelley GA, Ray CA, et al. American College of Sports Medicine position stand. Exercise and hypertension. Med Sci Sports Exerc. 2004;36(3):533-553; doi: 10.1249/ 01.mss.0000115224.88514.3a.

71. Maeda S, Miyauchi T, Iemitsu M, Sugawara J, Nagata Y, Goto K. Resistance exercise training reduces plasma endothelin-1 concentration in healthy young humans. J Cardiovasc Pharmacol. 2004;44(Suppl. 1):S443-S446; doi: 10.1097/01.fjc.0000166319.91623.b0.

72. Bank AJ, Shammas RA, Mullen K, Chuang PP. Effects of short-term forearm exercise training on resistance vessel endothelial function in normal subjects and patients with heart failure. J Card Fail. 1998;4(3):193201; doi: 10.1016/s1071-9164(98)80006-7.

73. Lewington S, Clarke R, Qizilbash N, Peto R, Collins R, Prospective Studies Collaboration. Age-specific relevance of usual blood pressure to vascular mortality: a meta-analysis of individual data for one million adults in 61 prospective studies. Lancet. 2002;360(9349): 1903-1913; doi: 10.1016/s0140-6736(02)11911-8.

74. Stewart KJ, Bacher AC, Turner KL, Fleg JL, Hees PS, Shapiro EP, et al. Effect of exercise on blood pressure in older persons: a randomized controlled trial. Arch Intern Med. 2005;165(7):756-762; doi: 10.1001/archinte. 165.7.756.

75. Wright JT Jr, Whelton PK, Reboussin DM. A randomized trial of intensive versus standard blood-pressure control. N Engl J Med. 2016;374(23):2294; doi: 10.1056/NEJMc1602668.

76. De Sousa EC, Abrahin O, Ferreira ALL, Rodrigues RP, Alves EAC, Vieira RP. Resistance training alone reduces systolic and diastolic blood pressure in prehypertensive and hypertensive individuals: meta-analysis. Hypertens Res. 2017;40(11):927-931; doi: 10.1038/ hr.2017.69.

77. Sirico F, Fernando F, Di Paolo F, Adami PE, Signorello MG, Sannino G, et al. Exercise stress test in apparently healthy individuals - where to place the finish line? The Ferrari corporate wellness programme experience. Eur J Prev Cardiol. 2019;26(7):731-738; doi: 10.1177/ 2047487318825174.

78. Beniamini Y, Rubenstein JJ, Faigenbaum AD, Lichtenstein AH, Crim MC. High-intensity strength training of patients enrolled in an outpatient cardiac rehabilitation program. J Cardiopulm Rehabil. 1999;19(1):817; doi: 10.1097/00008483-199901000-00001.

79. McCartney N, McKelvie RS, Haslam DR, Jones NL. Usefulness of weightlifting training in improving strength and maximal power output in coronary artery disease. Am J Cardiol. 1991;67(11):939-945; doi: 10.1016/0002-9149(91)90164-g.
80. Leon AS, Franklin BA, Costa F, Balady GJ, Berra KA, Stewart KJ, et al. Cardiac rehabilitation and secondary prevention of coronary heart disease: an American Heart Association scientific statement from the Council on Clinical Cardiology (Subcommittee on Exercise, Cardiac Rehabilitation, and Prevention) and the Council on Nutrition, Physical Activity, and Metabolism (Subcommittee on Physical Activity), in collaboration with the American Association of Cardiovascular and Pulmonary Rehabilitation. Circulation. 2005;111(3): 369-376; doi: 10.1161/01.CIR.0000151788.08740.5C.

81. Wilke NA, Sheldahl LM, Tristani FE, Hughes CV, Kalbfleisch JH. The safety of static-dynamic effort soon after myocardial infarction. Am Heart J. 1985;110(3): 542-545; doi: 10.1016/0002-8703(85)90072-9.

82. Ji H, Fang L, Yuan L, Zhang Q. Effects of exercise-based cardiac rehabilitation in patients with acute coronary syndrome: a meta-analysis. Med Sci Monit. 2019;25: 5015-5027; doi: 10.12659/MSM.917362.

83. Heran BS, Chen JM, Ebrahim S, Moxham T, Oldridge N, Rees K, et al. Exercise-based cardiac rehabilitation for coronary heart disease. Cochrane Database Syst Rev. 2011;7:CD001800; doi: 10.1002/14651858. CD001800.pub2.

84. Hare DL, Ryan TM, Selig SE, Pellizzer AM, Wrigley TV, Krum H. Resistance exercise training increases muscle strength, endurance, and blood flow in patients with chronic heart failure. Am J Cardiol. 1999;83(12):16741677; doi: 10.1016/s0002-9149(99)00179-4.

85. Piña IL, Apstein CS, Balady GJ, Belardinelli R, Chaitman BR, Duscha BD, et al. Exercise and heart failure: a statement from the American Heart Association Committee on Exercise, Rehabilitation, and Prevention. Circulation. 2003;107(8):1210-1225; doi: 10.1161/01. cir.0000055013.92097.40.

86. Yamamoto S, Hotta K, Ota E, Mori R, Matsunaga A. Effects of resistance training on muscle strength, exercise capacity, and mobility in middle-aged and elderly patients with coronary artery disease: a meta-analysis. J Cardiol. 2016;68(2):125-134; doi: 10.1016/j.jjcc. 2015. 09.005 .

87. Grönefeld GC, Lilienthal J, Kuck KH, Hohnloser SH, Pharmacological Intervention in Atrial Fibrillation (PIAF) study investigators. Impact of rate versus rhythm control on quality of life in patients with persistent atrial fibrillation. Results from a prospective randomized study. Eur Heart J. 2003;24(15):1430-1436; doi: 10.1016/ s0195-668x(03)00261-6.

88. Osbak PS, Mourier M, Henriksen JH, Kofoed KF, Jensen GB. Effect of physical exercise training on muscle strength and body composition, and their association with functional capacity and quality of life in patients with atrial fibrillation: a randomized controlled trial. J Rehabil Med. 2012;44(11):975-979; doi: 10.2340/ 16501977-1039.

89. Hegbom F, Stavem K, Sire S, Heldal M, Orning OM, Gjesdal K. Effects of short-term exercise training on 


\section{HUMAN MOVEMENT}

S. Palermi et al., Chest press and cardiovascular disease

symptoms and quality of life in patients with chronic atrial fibrillation. Int J Cardiol. 2007;116(1):86-92; doi: 10.1016/j.ijcard.2006.03.034.

90. Hegbom F, Sire S, Heldal M, Orning OM, Stavem K, Gjesdal K. Short-term exercise training in patients with chronic atrial fibrillation: effects on exercise capacity, $\mathrm{AV}$ conduction, and quality of life. J Cardiopulm Rehabil. 2006;26(1):24-29; doi: 10.1097/00008483-2006 01000-00005.

91. Plisiene J, Blumberg A, Haager G, Knackstedt C, Latsch J, Norra C, et al. Moderate physical exercise: a simplified approach for ventricular rate control in older patients with atrial fibrillation. Clin Res Cardiol. 2008;97(11):820-826; doi: 10.1007/s00392-008-0692-3.

92. Guasch E, Mont L, Sitges M. Mechanisms of atrial fibrillation in athletes: what we know and what we do not know. Neth Heart J. 2018;26(3):133-145; doi: 10.1007/ s12471-018-1080-x.

93. Kiuchi MG, Chen S, Hoye NA. The effects of different physical activities on atrial fibrillation in patients with hypertension and chronic kidney disease. Kidney Res Clin Pract. 2017;36(3):264-273; doi: 10.23876/j.krcp. 2017.36.3.264.

94. World Health Organization. Global recommendations on physical activity for health. Available from: https:// www.who.int/dietphysicalactivity/factsheet_recommendations/en/.

95. Fragala MS, Cadore EL, Dorgo S, Izquierdo M, Kraemer WJ, Peterson MD, et al. Resistance training for older adults: position statement from the National Strength and Conditioning Association. J Strength Cond Res. 2019;33(8):2019-2052; doi: 10.1519/JSC.000000000 0003230.

96. Thow M (ed.). Exercise leadership in cardiac rehabilitation: an evidence-based approach. Hoboken: John Wiley \& Sons; 2006.

97. Biffi A, Fernando F, Adami PE, Messina M, Sirico F, Di Paolo F, et al. Ferrari Corporate Wellness Program: results of a pilot analysis and the "drag" impact in the workplace. High Blood Press Cardiovasc Prev. 2018; 25(3):261-266; doi: 10.1007/s40292-018-0266-z.

98. Ehsani AA, Heath GW, Hagberg JM, Sobel BE, Holloszy JO. Effects of 12 months of intense exercise training on ischemic ST-segment depression in patients with coronary artery disease. Circulation. 1981;64(6):11161124; doi: 10.1161/01.cir.64.6.1116.

99. McKelvie RS, McCartney N. Weightlifting training in cardiac patients. Considerations. Sports Med. 1990; 10(6):355-364; doi: 10.2165/00007256-19901006000003. 